\title{
Grand Design of Character Education Based on Islamic Values
}

\author{
Pairin, Badarwan, Syahrul \\ Department of Islamic Education \\ Institut Agama Islam Negeri (IAIN) \\ Kendari, Indonesia \\ pairin@iainkendari.ac.id
}

\begin{abstract}
This article aims to provide a critical picture of the great design of character education in Kendari. The aspects that are explored: 1) the vision of character education based on Islamic religious values; 2) mission of character education based on Islamic religious values; 3) character education programs based on Islamic values. The type of research used is qualitativedescriptive. The research findings show: 1) the vision of character education based on Islamic religious values is very well described; 2) the mission of character education based on Islamic values describes a series of systematic agendas, showing the main tasks for achieving vision; 3) The character education programs are practical forms of character education based on Islamic values, which combine with competencies between teachers in their own team.
\end{abstract}

Keywords—vision; mission; character education

\section{INTRODUCTION}

Educational process is the process of developing student's potential until they become the heirs and the developer of nation's culture. The education should to give a foundation with all the aspect that needs for sustainability nation's life to reflect their personality[1]. Education in Indonesia aims to develop the potential of students to become human beings who believe and fear the Almighty God, are noble, capable, creative, independent, become democratic and responsible citizens [2]. The purpose of education is certainly inseparable from the goal of Islamic education, as a religion adopted by the majority of Indonesian people, namely forming a noble personality.

Tobroni in Iqbal, stated that in educational activities, the goals or ideals are formulated in the ultimate aims of education in a concise and concise manner. The purpose of Islamic education is usually described in two perspectives, namely the ideal (personal) human and ideal (social being) society. Ideal human perspectives such as "insan kamil", "human beings," "Muslim paripurna", "human beings who have faith and science and technology" and so forth. While the ideal form of society is "civil society", "the main community" and so on [3]. This indicates that Islamic education has a broad goal and according to human needs as individual and social beings inspired by the teachings of Islam.

In fact, Islamic education is in the spotlight of the public, when there is a deviant behavior of students from Islamic teachings, such as drug abuse, alcoholic drinks, free sex to brawl. The impact is on public order and security, so that various parties question the effectiveness of implementing Islamic education in schools.

The implementation of Islamic education in the school environment is currently faced with two major challenges both externally and internally. External challenges are more inclined to changes that occur in people's lives because of the rapid advancement of science and technology. While internal challenges tend to be different from the public's view of the existence of character education. There are those who view that Islamic Education is just an ordinary subject and do not need to have a clear purpose, even said the philosophical foundation for implementing Islamic religious education and planning programs for implementing Islamic Education is less clear [4].

The active and creative role of teachers is highly demanded to hold extracurricular activities that can support the learning of Islamic Education, especially in instilling the values of Islamic education in students, through exemplary and habituation in their environment. Responsibility in preparing future generations must be thoroughly thought out and carefully planned.

Related to the explanation above, it is interesting to pay attention to the Ummushshabri Islamic Boarding School which is becoming the prima donna of basic education in Kendari. Based on concerns over the current state of education that is considered to be unable to accommodate various problems of students, this institution sparked the concept of CIBI education (intelligent Islamic intellectual intellectuals) and CIBER (intelligent religious gifted intellectuals). The practice is the design of learning in the classroom accompanied by a teaching team of three people, namely Islamic religious teachers, science teachers, and psychology. The community has benefited from the application of this concept, they acknowledged that attending the Ummushshabri Islamic Boarding School had great added value, which was not obtained in other schools.

This article aims to make a critical overview of the great design of character education based on Islamic values in the Ummushshabri Islamic Boarding School, which includes three aspects, such as; 1) vision of character education based on Islamic values in the Ummushshabri Islamic Boarding School; 
3) character education mission based on Islamic values in the Ummushshabri Islamic Boarding School; 3) character education programs based on Islamic values in the Ummushshabri Islamic Boarding School.

\section{METHOD}

This article is the result of research conducted at the Kendari Ummushshabri Islamic Boarding School in Southeast Sulawesi. The key informants are Pesantren leaders, teachers, santri, and the community. Data obtained in the form of primary data and secondary data.

The problem solving process of this study uses a type of qualitative research with descriptive techniques [5]. Data collection is done through interviews, observations, and document studies [6]. Data analysis uses stages of reduction, presentation, and conclusion. Assurance of data validity is done through the process of extending observations, increasing perseverance, re-examining informants, and triangulating [7].

\section{RESULTS AND DISCUSSION}

Character education is important for human life, so the role played by education must not only show moral knowledge, but also love and want to take moral actions [8]. One form of moral action is to build educational institutions that implement character education. The Islamic boarding school Ummushshabri has a strong breath in the context of character education. The model search process has been carried out in a fairly long period of time. Starting from the application of the pesantren model that is commonly known to the public, to self-proclaimed as a metropolitan boarding school. And currently carrying out the CIBI and CIBER programs at the level of Madrasah Ibtidaiyah and Madrasah Tsanawiyah.

\section{A. Vision of Character Education Based on Islamic Values at Pesantren Ummushshabri Kendari}

The strong desire of an institution to give an important influence on social interaction can be seen from its views about the future, which manifest in the vision of the organization. Likewise, the Ummushshabri Islamic Boarding School affirms its commitment in character education in the vision of "Shaleh, Islamic, Achieving, Populist and Social".

First, piety is obedient or consistent in carrying out the Shari'a both ritual and social. Its forms include: 1) Making Islamic law as a support for daily living at home and in the madrasa; 2) Carry out fardhu (dhuhur) prayers in congregation at the Ummusshabri Islamic Boarding School; 3) Cultivating dhuha prayers together before entering the classroom begins with the tadarrus al-Qur'an for 10-15 minutes; 4) Building a culture of mutual respect and respect among fellow teachers, teachers with students, and fellow students; 5) Maintain and maintain the cleanliness of the madrasa environment; 6) Building discipline in worship; 7) Be Islamic and behave.

Second, Islam, which is to build a santri culture by creating an Islamic nuance of all activities, including: 1) Cultivating greetings in the daily lives of students and teachers in the madrasa; 2) Cultivation of basmallah readings every time starting activities and reciting ham in ending activities; 3) Taddarus activities before the lesson begins as personality development; 4) Pray the Dhuha before entering the first lesson; 5) Dhuhur prayer in congregation during recess; 6) Following a short lecture (cult) every after the dhuhur prayer by MIS and Aliyah students; 7) Familiarize conversations in Arabic (muhadatsah) and read the Qur'an through selfdevelopment; 8) Together with the community carrying out religious activities related to the remembrance of Islamic holidays; 9) Integrate all general subjects with aspects of Islam.

Third, achievement is trying to make maximum achievements in various aspects, including: 1) Achieving the National Examination score; 2) Achieving in the field of religious skills; 3) Achieving in the field of science mastery; 4) Achieving in the field of language (Arabic and English); 5) Achieving in the field of extracurricular activities; 6) Achieving cleanliness and order.

Fourth, populism and community, that is, besides being known by the community, also has sensitivity to social problems, through: 1) From an early age, it is cultivated to communicate in Arabic and English in the madrasa environment; 2) Increased academic achievement; 3) Increased extra-curricular achievements; 4) Winning in various race events, especially religious art competitions between MI / SD in District / City, Province, and National; 5) Instill social solidarity by also helping the community to help citizens who need help.

\section{B. Mission of Character Education Based on Islamic Values at Pesantren Ummushshabri Kendari}

The Ummushshabri Islamic Boarding School mission in Kendari is as follows: 1) Growing appreciation and practicing Islamic values and daily culture at home and in the madrasa; 2) To develop students' academic potential optimally according to their talents and interests through the learning process; 3) Carry out effective learning and guidance to students in the field of mastery of natural knowledge to be able to compete with public schools; 4) Develop the potential of students through sports and arts activities and extracurricular activities to foster discipline and develop creativity; 5) Optimizing the competence of the madrasa community in providing services to students and the community using education; 6) Implement participatory management by involving madrasa residents and stakeholders; 7) Make maximum use of the madrasa environment as a learning resource, practice religious knowledge and skills; 8) Improve coordination and cooperation with parents and related agencies in the development of the Pesri Kendari MIS; 9) Intensifying synergies with SD and fellow Public and Private MIs to share the development of madrasas.

\section{Character Education Program Based on Islamic Values at Pesantren Ummushshabri Kendari}

The Islamic Talented Intelligence or Intelligence Program at the Ibtidaiyah Madrasah level, and CIBER or Religious Gifted Intellectual Intelligence are the flagship programs of the Ummushshabri Islamic Boarding School. The practice of 
classroom learning is guided by three teachers in different scientific fields, namely: religion, science, and psychology. This program gets very high appreciation from the community, so that every year the school always gets abundant new students.

\section{CONCLUSION}

Concern about the future of the young generation is not only the main point of the need for character education. Because the problem of character is not only the issue of morality, but also the preparation of resilient human resources. Because the problem of character includes moral-spiritual, also physical-rationalistic dimensions. It takes an educational institution that is capable of carrying out moral actions by pioneering character education. The Ummushshabri Islamic Boarding School is one of the educational institutions that makes great designs on character education based on Islamic religious values, which are reflected in the vision and mission of the institution.

The implication of this paper is the importance of building sensitivity to social conditions, especially the condition of school-age children, understanding their long-term needs. Such understanding should lead us to strategic efforts through pioneering relevant educational institutions. Strengthening the character of students must be the main agenda in every schooling, both from the national and religious values.

\section{ACKNOWLEDGMENT}

The writing of this article can be realized because of the openness of the leadership and residents of the Ummushshabri boarding school, so that one more award should be conveyed, in addition to the efforts of goodness in organizing character education-oriented educational institutions. In addition, support from the academic community of IAIN Kendari helped launch the research process, which ultimately became the main writing of this article.

\section{REFERENCES}

[1] Daniel Tanner and Laurel Tanner, "Curriculum Development: Theory Into Practice,” Publisher: Pearson, Copyright 4, 2006.

[2] R. Indonesia, "Undang-Undang Republik Indonesia Nomor 20 Tahun 2003 Tentang Sistem Pendidikan Nasional," 2003.

[3] A. Fauzi, "Model Manajemen Pendidikan Islam; Tela'ah atas Pemikiran dan Tindakan Sosial," Ta'lim J. Pendidik., vol. 2, no. 2, pp. 19-37, 2017.

[4] S. Salahuddin, "Implementasi Kegiatan Ekstrakulikuler Rohis Dalam Pembinaan Akhlak Siswa Di Madrasah Aliyah Muhammadiyah 13 Sei Rampah Kabupaten Serdang Bedagai," Hijri, vol. 6, no. 1, pp. 238-248, 2017.

[5] [N. K. Denzin and Y. S. Lincoln, "The Sage Handbook of Qualitative Research," Sage Publ., pp. 1-1231, 2005.

[6] R. R. Sherman and R. B. Webb, Qualitative Research In Education: Focus and Methods. 2005.

[7] M. B. Miles and A. M. Huberman, "Qualitative Data Analysis: An Expanded Sourcebook." Sage Publication, 1994.

[8] A. Sudrajat, "Mengapa Pendidikan Karakter?," Pendidik. Karakter, vol. 1, no. 1, pp. $47-58,2011$. 